\title{
Gambaran Pasien Tuli Mendadak di Bagian THT-KL RSUP Dr. M. Djamil Padang
}

\author{
Hedo Hidayat ${ }^{1}$, Yan Edward ${ }^{2}$, Noza Hilbertina ${ }^{3}$
}

\begin{abstract}
Abstrak
Tuli mendadak adalah penurunan pendengaran sensorineural yang berlangsung dalam waktu kurang dari 72 jam. Penyakit ini merupakan salah satu kegawatdaruratan neurotologi dan memerlukan penatalaksanaan dini untuk menghindari kecacatan yang dapat ditimbulkan. Tujuan penelitian ini adalah melihat gambaran kejadian tuli mendadak di Bagian THT-KL RSUP Dr. M.Djamil. Ini merupakan penelititan deskriptif retrospektif dengan menggunakan data rekam medik di RSUP Dr. M. Djamil Padang selama tahun 2010 sampai tahun 2013. Didapatkan hasil sebanyak 26 kasus yang masuk kriteria inklusi pada periode tersebut. Sebaran umur penderita dari 8 sampai 79 tahun, dengan distribusi terbanyak pada usia $40-60$ tahun. Faktor resiko yang ditemukan berupa hipertensi dan diabetes melitus sama besar yaitu $11,54 \%$. Gejala klinis terdiri atas tinitus $(76,92 \%)$, diikuti vertigo $(38,46 \%)$, dan rasa penuh di telinga $(15,38 \%)$. Pasien terbanyak pada derajat ketulian sangat berat $(38,46 \%)$, kemudian derajat sedang berat dan berat $(23,08 \%)$, diikuti derajat ringan $(11,54 \%)$ dan sedang $(3,85 \%)$. Distribusi onset terapi terbanyak pada $0-7$ hari $(50,00 \%)$, kemudian onset $>14$ hari $(30,77 \%)$ dan onset $8-14$ hari $(19,23 \%)$. Perbaikan pendengaran ditemukan sama banyak pada kategori sangat baik dan baik sebanyak 6 kasus dan diikuti kategori sembuh satu kasus. Dari penelitian ini dapat dikatakan tidak hanya satu faktor yang menentukan perbaikan tuli mendadak.
\end{abstract}

Kata kunci: tuli mendadak, retrospektif, gejala klinis

\section{Abstract}

Sudden deafness is a sensorineural hearing loss in less than 72 hours. Sudden deafness is a neurotological emergency and requiring an early management to avoid the defects that can be caused. The objective of this study was to see cases of sudden deafness in Dr. M. Djamil General Hospital. This was a descriptive research with retrospective design using medical record data in Dr. M. Djamil General Hospital in Padang during 2010 to 2013. From the research, 26 cases were obtained that can meet the inclusion criteria in the period. The age ranged from 8 to 79 years old, with most distributions at age 40-60 years old. Risk factors, hypertension and diabetes mellitus, were found equally $11,54 \%$. Clinical symptoms consisted of tinnitus (76,92\%), followed by vertigo (38,46\%), and ear fullness $(15,38 \%)$. Using grades of hearing impairment, most of patients were classified profound impairment $(38,46 \%)$, then moderate and moderate severe impaitment (23,08\%), followed by slight (11,54\%) and moderate impairment (3,85\%). Most therapeutic onset distribution is 0-7 days (50,00\%), > 14 days onset (30,77\%) and onset 8-14 days (19,23\%). Hearing improvement was found equally in very good and good category (6 cases) and followed by recover category (1 case). It can be conclude that there were many factors can affect hearing improvement in sudden deafness case.

Keywords: sudden deafness, retrospective, clinical symptoms

Affiliasi penulis: 1. Pendidikan Dokter FK UNAND (Fakultas Kedokteran Universitas Andalas Padang), 2. Bagian THT-KL FK UNAND, 3. Bagian Patologi Anatomi FK UNAND

Korespondensi: Hedo Hidayat; Email: Icarmde443@gmail.com, Telp: +6285274677555

\section{PENDAHULUAN}

Tuli mendadak atau dikenal juga dengan sudden sensorineural hearing loss (SSHL) adalah penurunan pendengaran sensorineural $30 \mathrm{~dB}$ atau 
lebih, paling sedikit tiga frekuensi berturut-turut pada pemeriksaan audiometri dan berlangsung dalam waktu kurang dari 3 hari. Kerusakan terutama di koklea dan biasanya bersifat permanen, karena itu tuli mendadak dimasukkan ke dalam keadaan darurat neurotologi. ${ }^{1}$ Tuli mendadak diderita oleh 5 sampai 30 per 100.000 orang, dengan peningkatan sekitar 4000 kasus per tahun di Amerika Serikat. Suatu penelitian di Jerman menunjukkan kejadian tuli mendadak sebanyak 160 per 100.000 orang per tahunnya. ${ }^{2}$ Kejadian tuli mendadak di Italia dilaporkan antara 5 sampai 20 kasus per 100.000 orang. $^{3}$ Insiden tuli mendadak di poli THT-KL RSUP. Dr. M. Djamil Padang pada periode Agustuts 2010 sampai Agustus 2011 berkisar 37 orang. ${ }^{4}$ Distribusi laki-laki dan perempuan hampir sama, dengan puncak usia antara 50 sampai 60 tahun, ${ }^{3}$ namun penelitian di Taiwan pada tahun 1998 2002, menyatakan bahwa dari 8712 kasus tuli mendadak, $64,5 \%$ penderita berusia di atas 60 tahun. ${ }^{5}$ Perbaikan pendengaran pada tuli mendadak tergantung pada beberapa faktor yaitu, kecepatan pemberian obat, respon 2 minggu pengobatan pertama, usia, derajat ketulian saraf dan adanya faktor predisposisi. Pada umumnya makin cepat diberikan pengobatan makin besar kemungkinan untuk sembuh, bila sudah lebih dari 2 minggu kemungkinan sembuh menjadi lebih kecil. ${ }^{1}$ Oleh karena tuli mendadak merupakan salah satu kegawatdaruratan neurotologi, beratnya kecacatan yang dapat ditimbulkan, serta pentingnya diagnosis dan penatalaksanaan dini terkait penyakit tuli mendadak ini, maka perlu diteliti mengenai bagaimana gambaran pasien tuli mendadak di RSUP Dr. M Djamil Padang.

\section{METODE}

Penelitian ini merupakan deskriptif dengan desain retrospektif. Penelitian dilakukan di Bagian Rekam Medik RSUP Dr. M. Djamil Padang Februari 2014 - Mei 2014.

Populasi penelitian adalah seluruh pasien tuli mendadak yang terdata di rekam medis RSUP Dr. M. Djamil Padang periode 1 Januari 2010 - 31 Desember 2013. Sampel pada penelitian ini diambil dengan teknik total sampling yaitu seluruh populasi yang memenuhi kriteria inklusi dinyatakan sebagai sampel.
Kriteria inklusi pada penelitian ini adalah pasien yang didiagnosis sebagai tuli mendadak oleh dokter spesialis THT-KL, sedangkan kriteria eksklusi adalah pasien yang didiagnosis sebagai tuli mendadak oleh dokter spesialis THT-KL namun tidak memiliki data audiometri yang lengkap selama 2 minggu awal penatalaksanaan. Data yang diambil adalah jumlah penderita tuli mendadak, umur, faktor risiko, gejala klinis. derajat ketulian, perbaikan pendengaran dan onset terapi.

Pengolahan data dilakukan secara manual, dilakukan editing terhadap semua variabel yang diteliti kemudian dihitung jumlahnya dengan cara tabulasi. Data dianalisis dengan cara menentukan masingmasing variabel yang akan diteliti, kemudian disajikan dalam tabel distribusi frekuensi.

\section{HASIL}

Didapatkan 110 pasien tuli mendadak selama periode 1 Januari 2010 sampai 31 Desember 2013 melalui data rekam medik pasien, namun hanya 26 pasien yang masuk kriteria inklusi.

Tabel 1. Distribusi tuli mendadak berdasarkan usia

\begin{tabular}{ccc}
\hline $\begin{array}{c}\text { Usia } \\
\text { (Tahun) }\end{array}$ & Jumlah & $\%$ \\
\hline$<40$ & 7 & 26,92 \\
$40-60$ & 15 & 57,69 \\
$>60$ & 4 & 15,39 \\
\hline Jumlah & 26 & 100 \\
\hline
\end{tabular}

Ada 26 kasus tuli mendadak yang diteliti, penderita terbanyak ditemukan pada usia 40 - 60 tahun sebesar $57,69 \%$.

Tabel 2. Distribusi tuli mendadak menurut faktor risiko

\begin{tabular}{ccc}
\hline Faktor Risiko & Jumlah & $\%$ \\
\hline Hipertensi & 3 & 11,54 \\
Diabetes Melitus & 3 & 11,54 \\
Tidak ditemukan & 20 & 76,92 \\
\hline Jumlah & 26 & 100 \\
\hline
\end{tabular}

Faktor risiko yang ditemukan pada penderita tuli mendadak berupa hipertensi dan diabetes melitus ditemukan sama banyak sebesar $11,54 \%$. 
Tabel 3. Distribusi pasien tuli mendadak menurut gejala klinis

\begin{tabular}{ccc}
\hline Gejala Klinis & $\begin{array}{c}\text { Jumlah } \\
(\mathbf{n = 2 6 )}\end{array}$ & $\%$ \\
\hline Tinitus & 20 & 76,92 \\
Vertigo & 10 & 38,46 \\
Rasa penuh di telinga & 4 & 15,38 \\
\hline
\end{tabular}

Gejala klinis terbanyak adalah tinitus dengan persentase $76,92 \%$.

Tabel 4. Distribusi pasien tuli mendadak menurut derajat ketulian

\begin{tabular}{ccc}
\hline Derajat Ketulian & Jumlah & $\%$ \\
\hline Ringan & 3 & 11,54 \\
Sedang & 1 & 3,85 \\
Sedang berat & 6 & 23,08 \\
Berat & 6 & 23,08 \\
Sangat berat & 10 & 38,46 \\
\hline Jumlah & 26 & 100 \\
\hline
\end{tabular}

Derajat ketulian terbanyak adalah sangat berat yaitu sebesar $38,46 \%$.

Tabel 5. Distribusi perbaikan pendengaran menurut onset terapi pada minggu pertama tatalaksana

\begin{tabular}{|c|c|c|c|c|}
\hline \multirow{2}{*}{$\begin{array}{l}\text { Onset } \\
\text { (hari) }\end{array}$} & \multicolumn{4}{|c|}{ Perbaikan Pendengaran Minggu 1} \\
\hline & Tidak ada & Baik & $\begin{array}{c}\text { Sangat } \\
\text { baik }\end{array}$ & Sembuh \\
\hline $0-7$ & $\begin{array}{c}9 \\
(69,23 \%)\end{array}$ & $\begin{array}{c}2 \\
(15,38 \%)\end{array}$ & $\begin{array}{c}2 \\
(15,38 \%)\end{array}$ & - \\
\hline $8-14$ & $\begin{array}{c}2 \\
(40,00 \%)\end{array}$ & $\begin{array}{c}2 \\
(40,00 \%)\end{array}$ & $\begin{array}{c}1 \\
(20,00 \%)\end{array}$ & - \\
\hline$>14$ & $\begin{array}{c}6 \\
(75,00 \%)\end{array}$ & $\begin{array}{c}1 \\
(12,50 \%)\end{array}$ & - & $\begin{array}{c}1 \\
(12,50 \%)\end{array}$ \\
\hline
\end{tabular}

Tabel 6. Distribusi perbaikan pendengaran menurut onset terapi pada minggu kedua tatalaksana

\begin{tabular}{ccccc}
\hline $\begin{array}{c}\text { Onset } \\
\text { (hari) }\end{array}$ & \multicolumn{4}{c}{ Perbaikan Pendengaran Minggu 2 } \\
\cline { 2 - 5 } & Tidak ada & Baik & $\begin{array}{c}\text { Sangat } \\
\text { baik }\end{array}$ & Sembuh \\
\hline $0-7$ & 5 & 5 & 3 & - \\
& $(38,46 \%)$ & $(38,46 \%)$ & $(23,08 \%)$ & \\
$8-14$ & 2 & - & 3 & - \\
& $(40,00 \%)$ & & $(60,00 \%)$ & \\
$>14$ & 6 & 1 & - & 1 \\
& $(75,00 \%)$ & $(12,50 \%)$ & & $(12,50 \%)$ \\
\hline
\end{tabular}

Pada minggu pertama, 8 kasus mengalami perbaikan, dengan persentase tertinggi pada pasien dengan onset $8-14$ hari sebesar $60,00 \%$ (3 kasus), diikuti onset $0-7$ hari sebesar $30,76 \%$ (4 kasus) dan onset > 14 hari sebesar $12,50 \%$ (1 kasus).

Minggu kedua didapatkan 12 kasus mengalami perbaikan, dengan persentase tertinggi pada pasien dengan onset $0-7$ hari sebesar $61,54 \%$ (8 kasus), diikuti onset 8 - 14 hari sebesar $60,00 \%$ (3 kasus) dan $>14$ hari sebesar 12,50\% (1 kasus). Pasien sembuh hanya ditemukan pada pasien dengan onset $>14$ hari sebanyak 1 kasus $12,50 \%$ (1 kasus).

Tabel 7. Distribusi perbaikan pendengaran pada minggu kedua berdasarkan gejala tinitus

\begin{tabular}{ccccc}
\hline Gejala & \multicolumn{4}{c}{ Perbaikan Pendengaran Minggu 2 } \\
\cline { 3 - 5 } Tinitus & Tidak ada & Baik & $\begin{array}{c}\text { Sangat } \\
\text { baik }\end{array}$ & Sembuh \\
\hline Ada & 10 & 5 & 4 & 1 \\
& $(50,00 \%)$ & $(25,00 \%)$ & $(20,00 \%)$ & $(5,00 \%)$ \\
Tidak & 3 & 1 & 2 & - \\
ada & $(50,00 \%)$ & $(16,67 \%)$ & $(33,33 \%)$ & \\
\hline
\end{tabular}

Jumlah perbaikan pada pasien tanpa tinitus sebesar 50,00\% (3 kasus) dan pada pasien dengan tinitus sebesar 45,00\% (11 kasus). Pasien sembuh hanya ditemukan pada kasus dengan tinitus sebanyak $5,00 \%$ (1 kasus).

Tabel 8. Distribusi perbaikan pendengaran pada minggu kedua berdasarkan gejala vertigo

\begin{tabular}{ccccc}
\hline $\begin{array}{c}\text { Gejala } \\
\text { Vertigo }\end{array}$ & \multicolumn{4}{c}{ Perbaikan Pendengaran Minggu 2 } \\
\cline { 2 - 5 } & Tidak ada & Baik & Sangat baik & Sembuh \\
\hline Ada & 3 & 2 & 4 & 1 \\
& $(30,00 \%)$ & $(20,00 \%)$ & $(40,00 \%)$ & $(10,00 \%)$ \\
Tidak & 10 & 4 & & \\
ada & $(62,50 \%)$ & $(25,00 \%)$ & $(12,50 \%)$ & - \\
\hline
\end{tabular}

Dari penelitian ditemukan sebesar 10 kasus mengalami gejala vertigo. Jumlah perbaikan pendengaran pada kasus dengan vertigo sebesar $60,00 \%$ (6 kasus) dan pada pasien tanpa vertigo sebesar 37,50\% (6 kasus). Pasien sembuh hanya ditemukan pada kasus dengan vertigo sebanyak $10 \%$. 


\section{PEMBAHASAN}

Pada penelitian ini didapatkan 110 orang penderita tuli mendadak di bagian THT-KL RSUP Dr. M. Djamil Padang periode tahun 2010 sampai tahun 2013. Sebanyak 26 yang masuk dalam kriteria inklusi diambil sebagai sampel dan 84 kasus lainnya masuk dalam kriteria eksklusi. Penyebab banyaknya kasus yang masuk kriteria eksklusi adalah pasien tidak tidak datang follow-up pemeriksaan audiometri sehingga hasil pemeriksaan yang tercantum di rekam medik tidak lengkap.

Kisaran umur penderita antara 8 - 79 tahun. Penderita terbanyak pada penelitian ini berada pada kelompok usia 40 - 60 tahun sebanyak 57,69\%. Hasil ini sejalan dengan penelitian yang dilakukan $\mathrm{Wu}$ et al di Taiwan yang menemukan penderita terbanyak berada pada kelompok usia 40 - 60 tahun sebanyak $40,51 \%{ }^{6}$ Gangguan vaskular dan infeksi virus memang dapat menimbulkan tuli mendadak, namun studi yang telah ada tidak mendukung etiologi viral ataupun vaskular sebagai penyebab umum. Pembuktian teori imunologi sebagai penyebab umum dari tuli mendadak juga masih lemah. ${ }^{7}$ Penyebab umum dari tuli mendadak masih belum dapat dipastikan dan membutuhkan penelitian lebih lanjut, sehingga penyebab puncak usia penderita tuli mendadak berada pada kelompok 40 - 60 tahun belum dapat diketahui.

Faktor risiko berupa hipertensi dan diabetes melitus ditemukan sama banyak pada penderita yaitu sebesar $11,54 \%$. Hasil penelitian ini berbeda dengan Lin et al yang menemukan penderita dengan hipertensi sebanyak $6,8 \%$ dan diabetes melitus sebanyak $6,7 \% .^{5}$ Perbedaan ini mungkin disebabkan oleh tidak ratanya pembagian sampel pada penelitian ini dan adanya sampel yang masuk kriteria eksklusi sehingga mempengaruhi persentase hasil penelitian.

Tinitus merupakan gejala klinis terbanyak yang ditemukan pada penderita sebesar $76,92 \%$. Vertigo merupakan gejala klinis kedua terbanyak yang ditemukan sebesar $38,46 \%$ dan rasa penuh ditelinga sebesar 15,38\%. Penelitian yang dilakukan Ballesteros et al menemukan data yang hampir sama yakni $69,5 \%$ penderita mengalami tinitus, 33,1\% pasien mengalami vertigo dan $30 \%$ mengalami rasa penuh di telinga. ${ }^{8}$ Tinitus adalah gejala yang paling sering menyertai tuli mendadak. Ada ahli yang berpendapat bahwa adanya tinitus menunjukkan prognosis yang lebih baik. Sedangkan adanya vertigo menandakan prognosis yang buruk, meskipun tidak semua peneliti setuju mengenai hal ini. ${ }^{1,}$

Derajat ketulian terbanyak yang ditemukan adalah sangat berat sebesar 38,46\%. Diikuti derajat sedang berat dan berat yang ditemukan sama banyak sebesar 23,08\%. Derajat ketulian ringan ditemukan sebesar $11,54 \%$ dan derajat ketulian sedang sebesar $3,85 \%$. Penelitian yang dilakukan Ballesteros et al menemukan pasien dengan derajat ketulian sangat berat $(>90 \mathrm{~dB})$ sebesar $14 \%$, derajat berat $(71-90$ $\mathrm{dB}$ ) sebesar $39 \%$, sedang $(41-70 \mathrm{~dB})$ sebesar $41 \%$ dan ringan $(21-40 \mathrm{~dB})$ sebesar $6 \% .^{8}$ Derajat ketulian yang muncul pada penderita tuli mendadak bervariasi pada masing-masing penderita dan akan menentukan prognosis dari penyakit ini. Semakin parah kehilangan pendengaraannya, semakin rendah kemungkinan untuk penyembuhan dan kehilangan pendengaran derajat sangat berat memiliki prognosis yang sangat buruk pula. ${ }^{9}$

Perbaikan pendengaran pada minggu pertama terapi sebanyak 8 kasus $(30,77 \%)$. Kemudian pada minggu kedua terjadi peningkatan menjadi 12 kasus (46,15\%). Pasien sembuh tidak mengalami peningkatan jumlah yakni tetap 1 kasus (3,85\%). Studi yang dilakukan di Barcelona Spanyol oleh Ballesteros et al menemukan pasien dengan perbaikan sebesar $40,7 \%{ }^{8}$ Derajat perbaikan pendengaran, parsial ataupun total, pada penderita tuli mendadak berkisar antara $35 \%$ sampai $65 \%{ }^{9}$

Prognosis tuli mendadak tergantung pada beberapa faktor yaitu kecepatan pemberian pengobatan, respon 2 minggu pengobatan pertama, usia, derajat ketulian dan adanya faktor predisposisi. Pada pasien dengan onset $0-7$ hari dapat terjadi peningkatan jumlah pasien yang mengalami perbaikan pendengaran dari 30,76\% (4 kasus) pada minggu pertama menjadi $61,54 \%$ (8 kasus) pada minggu kedua, sedangkan pada pasien dengan onset $8-14$ dan $>14$ hari tidak menunjukkan adanya peningkatan jumlah pasien yang mengalami perbaikan pendengaran. Pasien sembuh sebanyak satu kasus justru ditemukan pada kasus dengan onset $>14$ hari. Ini mungkin dikarenakan pada kasus tersebut derajat 
ketulian yang diderita adalah derajat ringan. Pada umumnya semakin cepat diberikan pengobatan semakin besar kemungkinan untuk sembuh, bila sudah lebih dari dua minggu kemungkinan sembuh menjadi lebih kecil.

Adanya tinitus memberikan prognosis lebih baik karena menandakan masih adanya fungsi pendengaran. ${ }^{4}$ Tetapi beberapa penelitian menyatakan bahwa prognosis tuli mendadak tidak dipengaruhi ada tidaknya tinitus. Kasapoglu et al menemukan $82,6 \%$ pasien tuli mendadak dengan gejala tinitus tidak ditemukan perbedaan perbaikan yang signifikan antara pasien dengan tinitus dan tanpa tinitus. ${ }^{10}$ Pada penelitian ini juga menemukan perbandingan perbaikan yang hampir sama, yakni sebesar 50,00\% (3 kasus) pada pasien tanpa tinitus dan 45,00\% (11 kasus) pada pasien dengan tinitus. Namun pasien sembuh hanya ditemukan pada pasien dengan tinitus sebesar $5,00 \%$.

Adanya vertigo mempunyai prognosis yang lebih buruk dibandingkan tidak disertai vertigo, karena adanya vertigo menandakan adanya kerusakan yang sudah mengenai sistem keseimbangan. Namun Fetterman et al, yang dikutip oleh Kasapoglu $\mathrm{F}$ et al menyatakan bahwa vertigo tidak mempengaruhi perbaikan pendengaran pada pasien tuli mendadak. ${ }^{10}$ Pada penelitian ini, 10 kasus dengan vertigo memiliki persentase perbaikan yang lebih besar, sebesar $60,00 \%$ (6 kasus), dibandingkan dengan pasien tanpa vertigo sebesar $37,50 \%$ (6 kasus). Ini mungkin disebabkan karena beberapa sampel masuk ke dalam kriteria eksklusi sehingga mempengaruhi hasil penelitian.

\section{KESIMPULAN}

Sebaran umur penderita adalah mulai dari 8 sampai 79 tahun. Penderita terbanyak ditemukan pada kelompok umur 40 sampai 60 tahun.

Faktor risiko berupa hipertensi dan diabetes melitus ditemukan sama banyak.

Tinitus merupakan gejala klinis terbanyak yang ditemukan pada penderita tuli mendadak.

Derajat ketulian penderita paling banyak adalah derajat sangat berat.

Onset terapi terbanyak pada pasien tuli mendadak berada pada kelompok Onset $0-7$ hari.
Dari 26 kasus tuli mendadak 12 kasus mengalami perbaikan, kategori baik dan sangat baik masing-masing 6 kasus, dan hanya 1 kasus yang sembuh.

\section{DAFTAR PUSTAKA}

1. Bashiruddin J, Soetirto I. Tuli mendadak. Dalam: Soepardi EA, Iskandar N, Bashiruddin J, Restuti R $\mathrm{D}$, editor (penyunting). Buku ilmu ajar kesehatan telinga hidung tenggorok kepala dan leher. Vol. 6; 2012. hIm.39-41.

2. Schreiber BE, Agrup C, Haskard DO, Luxon LM. Sudden sensorineural hearing loss. Lancet. 2010;375:1203-11.

3. Greco A, Fusconi M, Gallo A, Marinelli C, Macri G F, Vicentiis M D. Sudden sensorineural hearing loss: an autoimmune disease? Autoimmunity Reviews. 10(201):756-61.

4. Munilson J, Yurni. Diagnosis dan penatalaksanaan tuli mendadak. 2012 (diunduh 9 September 2013). Tersedia dari: URL: HYPERLINK http://repository. unand.ac.id/18123/

5. Lin HC, Lee HC, Chao PZ, Wu CS. The effects of weather on the incidence of sudden sensorineural hearing loss: a 5-year population-based study. Audiol Neurotol. 2006;11:165-71.

6. Wu CS, Lin HC, Chao PZ. Sudden sensorineural hearing loss: evidence from Taiwan. Audiol Neurotol. 2006;11:151-6.

7. Merchant SN, Durand ML, Adams JC. Sudden deafness: is it viral? ORL. 2008;70:52-62.

8. Ballesteros F, Tassies D, Reverter J C, Alobid I, Bernal-Sprekelsen M. Idiopathic sudden sensorineural hearing loss: classic cardiovascular and new genetic risk factors. Audiol Neurotol. 2012;17:400-8.

9. Arts HA. Sensorineural hearing loss in adult. Dalam: Flint PW, Haughey BH, Lund VJ, Niparko J $\mathrm{K}$, Richardson M A, Robbins $\mathrm{K} \mathrm{T}$, et al editor (penyunting). Cummings otolaryngology head \& neck surgery. Edisi ke-5; 2010. hlm.2127 - 30.

10. Kasapoglu F, Tuzemen G, Hizalan I, Erisen L, Basut $\mathrm{O}$, Onart $\mathrm{S}$, et al. Prognosis in sudden hearing loss: is it the disease or the treatment that determines the prognosis ? Int. Adv. Otol. 2009;5(2): 187-94 